\title{
Peace Building in the Balkans: Is There a Need to Stay the Course?
}

\author{
Frederic Labarre ${ }^{1}$
}

A year ago, Thomas L. Friedman published an already-famous article in which he claimed that democracy was sprouting tentatively in the ethnically pure states of the former Yugoslavia, whereas in multi-ethnic Bosnia, democratic development was farther from the goal set by the Dayton Accords than ever. Mr. Friedman's thesis is that Dayton's provisions should be abandoned, Bosnians (whatever their constituency) should decide for themselves where they want to live, and then let democracy take hold after the populations have "parted." Only this, Friedman feels, can help Bosnians to think beyond tribal interests, concluding that it is "not an accident McDonald's still refuses to operate [there]. ${ }^{2}$

These calls to abdicate any responsibility for promoting the ideal of multiethnic coexistence as framed by the Dayton Peace Accords (DPA) are not infrequent. The International Crisis Group pointed out in its December 2000 report that elections were only helping to dig deeper divisions between communities by allowing extremists to perpetuate their strangle hold on power. ${ }^{3}$ The ICG believes that it is time to rethink the DPA's strategy of elections as a means of speeding up democratic development and allowing a NATO pullout. It advocates that the international community take all the measures allowed by the Dayton Accords to enforce compliance by the parties, instead of putting its faith blindly in a democratic ethos that is simply not emerging. Implicit in this assessment is the notion that, since the implementation of Dayton seems too difficult, its usefulness comes into question as a matter of consequence. By extension, amendment of the DPA or its eradication would nullify the possibility of multi-ethnicity. The ICG's position is tantamount to revisionism.

These positions are similar, but there are nuances. Mr. Friedman would have the international community preside over a more or less formal "population exchange" that would see Croatia and Serbia inherit a form of "sphere of influence" over their respective populations in Bosnia, while NATO would take on the spon-

\footnotetext{
${ }^{1}$ Frederic Labarre, a former Advisor to the Ministry of Defense of Estonia, is currently resident at the Royal Military College, Kingston, Ontario, Canada. This paper was originally delivered at the $2^{\text {nd }}$ Reichenau Workshop of the PfP Consortium's Working Group "Crisis Management in South East Europe."

2 Thomas L. Friedman, "Not Happening," New York Times, 23 January 2001, section A, p. 21. The comment on McDonald's is in reference to a study that claims (correctly) that no two countries containing McDonald's restaurants have ever fought wars against each other.

3 ICG Balkan Report \#104, "Bosnia's November Elections: Dayton Stumbles", Sarajevo/Brussels, 18 December 2000, executive summary.
} 
sorship of a "Sarajevo Muslim mini-state"4 This approach would scrap six years of Dayton efforts in favor of something that the international community has been trying to prevent in the first place: chauvinistic nationalism bent on reassembling various ethnic communities within what they claim as their "historical territories." Against this, the ICG advocates an increase of pressure within the framework of Dayton. In other words, it proposes the evolution of mandates from the high officers of the international community, such as the Office of the High Representative of the UN. ${ }^{5}$ The two positions can be summarized by this question: Must the Balkan peace-building process (within the DPA framework) stay the course or not?

It is central to the assumptions underpinning the answer to this question discussed here that there are grounds to defend the ideal of multi-ethnicity that transcend Balkan power balances. If the Balkans are allowed to sprout as many precedents for secessions and territorial unions as there are nations, then other disgruntled groups outside the Balkans may invoke these precedents for their own claims, threatening the territorial integrity of countries that have harbored national minorities peacefully for centuries. The case made here is that the DPA-triggered peace process is adequate as it is, and that successful implementation depends more on political will than on the DPA itself as a document. In criticizing the lack of progress on the ground, DPA abdicators and revisionists place too much blame on the framework, without regard for the deeds that (should) follow in its support, both from the communities and from external actors working in support of peace.

This paper is divided into three sections. The first deals with the "abdicators" claims, because they need to be addressed, for not all of them are entirely accurate. The second answers the claims of "revisionists" by matching conflict resolution theory with the achievements of the DPA regime. The third matches the achievements of various actors working in the service of peace with the provisions of the DPA. It shows that, while absolute success is not yet at hand, there have been numerous breakthroughs, and that the situation is ripe for further improvements.

The essay concludes that not only are peace and democracy not antithetical to multi-ethnic coexistence, but that the prospect of seeing it implemented in the Balkans is real, because the setbacks encountered recently are neither the fruit of ethnic hatred nor of a faulty peace deal.

\section{PART 1: Countering preconceptions and assumptions}

Thomas Friedman's analysis is illustrative of the opinion of those who advocate a rapid troop pullout and the abandonment of the DPA as a tool for bringing self-sustaining peace to the Balkan region. Those who hold this opinion can be

\footnotetext{
${ }^{4}$ Friedman, op. cit.

${ }^{5}$ ICG \#104, op. cit.
} 
described as "abdicators," since they wish to abdicate any responsibility for promoting peace in the Balkans. There is some consensus surrounding this position, but it is flawed in many respects. Outlining its basic features, and attempting to refute some of them, is necessary.

The first thing that should be said is that the overarching goal in the Balkans is to prevent further state disintegration and the emergence of separatist parties, such as in Kosovo. The existence of these parties belies the notion that Serbia is ethnically pure; Kosovo's majority is ethnic Albanian, and Kosovo is still a province of Serbia proper (at least in law, if not in fact). The assumption that the Kostunica regime enjoyed a peaceful transition also entertains some distortion of facts. The transition was not that peaceful, and the Kostunica regime, albeit an extraordinary and welcome improvement over the Milosevic regime, faces many challenges which make it unreasonable to accurately assess its "decency" so early. Serb officials did meet with NATO Secretary General Lord Robertson, ${ }^{6}$ the Serbian government is actively trying to improve the security situation in Southern Kosovo, ${ }^{7}$ and the country is rapidly breaking out of its isolation, but the delay in extraditing Slobodan Milosevic did create some doubts. This delay was not contingent on President Kostunica's will alone, but on the occasion of the November elections in Bosnia, in which Milosevic supported the SDS, a Dayton-resistant party whose most famous member (and founder) is none other than indicted war criminal Radovan Karadzic ${ }^{8}$. So the question is: Does Milosevic enjoy remnants of personal or political power with a support base that could threaten Kostunica? The level of support enjoyed by Slobodan Milosevic can be more readily evaluated now that he is under arrest than during the elections last fall, and events so far seem to indicate that a challenge to President Kostunica is unlikely. At the same time, the peculiarities of Balkan politics make it unwise to ascribe evil intentions to politicians supporting views unpalatable to Western tastes.

Saying that democracy and pluralism are going backward in Bosnia is not accurate. Refugees are returning, and elections are being held. The elections themselves, it is true, keep re-electing the candidates of whom Western powers are weary, but even this is less true now that Bosnia deemed itself worthy of a nonnationalist government for the first time in ten years. ${ }^{9}$ But should that be the criterion of success? Mr. Friedman certainly confuses goals and consequences in his analysis. The goal of the Dayton Accords is not to pull out NATO troops as soon

\footnotetext{
${ }^{6}$ NATO Press Release (2001) 020, 15 February 2001, "Statement by the Secretary General."

${ }^{7}$ NATO Press Release (2001) 017, 9 February 2001, "Statement by the Secretary General on the Covic Peace Plan." See also Jolyon Naegele, "Yugoslavia: Serbia Offers Peace Plan for Presevo Valley," Radio Free Europe/Radio Liberty 5 February 2001, www.rferl.org.

${ }^{8}$ ICG, op. cit.

9 "Bosnia Gets First Non-nationalist Government in 10 Years", Reuters, Sarajevo, February 22 2001, via www.centraleurope. com/news.php3 $i d=295540 \&$ brief $=$ text.
} 


\section{THE QUARTERLY JOURNAL}

as possible. It is quite likely that troops would remain in Bosnia and Kosovo for a long time to come, even if democratic development exceeds expectations.

The goal of the accords is to ensure self-sustaining democracy and economic development, but troop pullouts should be a consequence of unambiguous improvements in the local security situation. And improvements of the security situation are not contingent on homogeneous ethnic communities. Rather, as Mr. Friedman himself says, the disappearance of Franjo Tudjman and Slobodan Milosevic from the political scene has allowed free and fair elections. Mr. Friedman uses two different concepts to compare Croatia and Serbia with Bosnia. He claims correctly that the downfall of the dictators has brought democracy to the first two, but that multi-ethnicity is to blame in Bosnia for its lack of progress toward democracy. The United States Institute of Peace (USIP) claims to the contrary in a recent report that states that the demise of the dictators provides fresh opportunities to make the DPA stick. ${ }^{10}$

Official obstructionism, not multi-ethnicity as a concept, is actively hindering progress in Bosnia and is making Dayton implementation so difficult. This is what an analysis of the peace effort suggests: first, that individuals-and not communities - are responsible for the lack of progress; second, that a more assertive implementation of the mandate and application of pressure to those resistant individuals is needed; and, third, that this is only one stage of the peace process. In that respect, it is not possible to determine where we should be five years on, because it is impossible to know how long it takes to achieve the desired peace. However, peace building theory can show where we are.

Concepts used by the abdicators do not help in understanding the difficulties the international community is facing on the ground in Bosnia (and in other conflicts around the world). Abandoning Dayton now would send the signal to Bosnia that it is just not worth the effort, that the lives of millions are not worth the $\$ 5$ billion invested so far (while the scores of millions of Western Europeans were worth Marshall Plan money after World War II). It would send a signal to thousands of field workers, some of whom are unpaid, that the legal basis for their efforts is flawed and is being scrapped. Scrapping Dayton would trigger doubts as to the capacity of great powers to craft a usable agreement, let alone implement it. It would tell soldiers who have risked their lives in the service of peace that their efforts are ineffective, and to the loved ones of those who have already made the supreme sacrifice that they have done so in vain. It would have consequences for the NGO community, which could lose its newfound status as a legitimate international actor in the post-Cold War era. It would deter donors and philanthropists from displaying their generosity, because the expense would be deemed

\footnotetext{
${ }^{10}$ Jon W. Western, "Bosnia's Next Five Years: Dayton and Beyond" (Washington, D.C.: USIP, USIP, September 2000), www.usip.org/oc/sr/sr001103/sr001103.html
} 
futile. And it would justify public apathy toward the plight of their neighbors in the global village.

True, the Dayton Accords are not perfect. Dr. Mihailo Crnobrnja has said, correctly, that they are not an "agreement," but rather they were arrived at because the "Americans slowly but firmly converted mediation of a dispute into enforcement of a settlement."11 Continued UN and military presence will be required for a long time to come in the Balkans. This would ring true even in the absence of the Dayton Accords, even with a perfect agreement. To give a sense of proportion to the task at hand, we need only compare the Dayton effort with traditional peacekeeping efforts. The UN has been in Cyprus for nearly 40 years $^{12}$ and, granted, has prevented violence there; thus no one questions the efficacy of UNFICYP. But the DPA calls for more than just an end to violence. It calls for self-sustaining, total, or positive peace.

\section{PART 2: Theory and aspects of conflict resolution}

The implementation of the Dayton Accords, whether freely arrived at or imposed, is necessary to achieve positive peace (freedom from want and fear) instead of negative peace (the simple absence of violence between parties). Achieving positive peace in the Balkans is like raising the Titanic and setting to sail again, an endeavor much more complicated than the already arduous proposition of rising from the abyss! The aim of this section is to demonstrate that the DPA and the accompanying proposition of multi-ethnic coexistence can succeed without amendments.

This is not the first time that modern conflict resolution practice has met with criticism. Tom Woodhouse has fruitfully refuted the claims of three critics of peace operations (particularly of peace operations in Africa) and, in so doing, has found that many do not acknowledge the different and successive stages a peace process goes through. This is also a problem with Mr. Friedman's analysis. He supposes that NATO troops and aid volunteers should be back home after five years, as does Michael O'Hanlon, with the difference that O'Hanlon recognizes the progress already made in Bosnia. ${ }^{13}$ In addition, critics put too much emphasis on the need for outsiders to solve the problem, claiming that, "in the perspective of peace building from below solutions are derived and built from local resources. ${ }^{14}$ According to the USIP, an excessive emphasis on "local empowerment" has been

\footnotetext{
${ }^{11}$ Mihailo Crnobrnja, "Moving Towards the End Game in Bosnia," Canadian Secret Intelligence Service, Commentary \#64, December 1995, www.csis.scrs.gc.ca/eng/comment/com64_e.html.

12 Alex Morrison, ed, "Global Situation Report of Current UN Peacekeeping and Related Operations" in Peacekeeping and International Relations 27:3-4 (Double issue, July-October 1998), (Clementsport, Nova Scotia: Pearson Peacekeeping Centre): 14-15.

${ }^{13}$ Michael O’Hanlon, “Troops Partly Come Home,” Foreign Affairs 80:2 (March-April 2001): 4.

${ }^{14}$ Tom Woodhouse, "International Conflict Resolution: Some Critiques and a Response," Centre for Conflict Resolution Working Paper \#1, June 1999, p. 26 (citing International Alert, Goodhand \& Lewer, Goodhand \& Hume).
} 
one reason for the lack of progress. ${ }^{15}$ This only further supports the point that efforts by major actors should not be discontinued, and should moderate local power holders' grip on the masses.

This last statement would seem at odds with the many pleas of the UN Secretary General for renewed involvement and support from the international community. In addition to the various stages of scaling down conflict, there is a division of labor between international actors and NGOs; Woodhouse's reference pertained mainly to NGOs. ${ }^{16}$ And there is no doubt that the work of NGOs has not met with the same obstruction as that of the UN, OSCE, or NATO, because NGOs are not thought to be politically dangerous. But to keep our reply consistent with the assumptions of abdicators and revisionists, this section will concentrate on intervention by major actors of the international community, so as to verify the impact of "outsiders" in favor of a lasting peace.

\section{Two doctrines}

Two broad doctrines have emerged in the search for positive peace. One is based on consensual constitution-making, followed by internationally monitored elections. The other calls for a provisional government whose task it is to introduce confidence-building measures under international supervision in order to restore trust and thence to begin the task of peace building, starting from a liberal constitution, followed by elections. ${ }^{17}$

In Bosnia, a variant of the first doctrine was used. It turned out to be a perversion, mainly because the parties did not negotiate in good faith, and because the terms of the agreement were pressed upon them, with the result that obstacles or difficulties may have deliberately been inserted in the final document. But if the intent for U.S. mediators was to ensure that the DPA led to justice predominating over mere negative peace, there is no question that these ideals are being implemented even if the DPA is not considered just in itself. By acting as a plan to favor justice, the DPA ensures that the remnants of the belligerent communities' healthy national pride are salvaged by placing blame where it belongs, and insisting on prosecution of war criminals. This is deemed essential if a self-sustaining, multi-ethnic peace is to take root. Already, the administrative successes brought about by the international community are contributing to a sense of normalcy ${ }^{18}$

This eases the work of the Hague Tribunal because the DPA is the expression of a consensus (albeit imposed) of all disputants. As a result, the work of various organizations named in the DPA is done in the service of the inherent understanding that individuals are to blame for the problems in the Balkans, not communities.

\footnotetext{
${ }^{15}$ Western, op. cit.

${ }^{16}$ Woodhouse, op. cit., p. 22.

${ }^{17}$ Ibid., p.4-5.

${ }^{18}$ Western, op. cit.
} 
This undermines the belief within these communities that the "other" is responsible for war, but instead points out that a perverted element of that community, evil because of selfish motives - and thus who cannot be associated with the aims of his community - is the perpetrator. This also stakes the ground over which reconciliation will in time be achieved.

Some DPA provisions, especially those pertaining to elections, allowed the ICG to predict that it was too early for Bosnians to go to the ballot box. It argued correctly that the outcome would simply confirm ethnic segregation by a stroke of the pencil. ${ }^{19}$ By the admission of the Organization of Security and Cooperation in Europe (OSCE) in a 1996 report, elections then (and since) have not been free and fair. ${ }^{20}$ Lately, election rules have been modified with the express intent to eliminate corrupt candidates, an initiative encouraged by the USIP. ${ }^{21}$ But it must be said that the mere action of reaching for the ballot box slot is morally superior to that of reaching for a clip of ammunition.

Conflict is seen as a wave whose crest usually culminates in a truce. In the case of Bosnia, this truce was more or less imposed. Nevertheless, a lessening of the violence, if not a lowering of tensions, generally follows. It is on the basis of a truce that traditional peacekeeping is possible. The UN tried traditional peacekeeping — the mere separation of belligerents with their consent—without success between 1991 and 1994. The following years saw NATO's first attempt at peace enforcement, or the imposition of peace. ${ }^{22}$ The results, judging by the statements of the abdicators and revisionists, are modest. Modern peacekeeping - the kind of mission that also takes into account such evolutions as peace building and peacemaking (notions that earned public acceptance in the wake of Boutros Boutros-Ghali's "Agenda for Peace" publication)—uses the notion of traditional peacekeeping as part of a process that encompasses peace enforcement, peacekeeping, peacemaking, and peace building. It intervenes, before other forces are set in motion, in the service of conflict resolution with the aim of achieving positive peace. Similarly, peace building - the term used to describe the concerted action of the international community and the work of NGOs and IO-intervenes after the fog of war has evaporated. Sometimes, organizations are anxious to help, and they often do not wait for hostilities to stop. This is the case of the Red Crescent and the Red Cross, Médecins sans Frontières, and even some less well-funded NGOs, such as Conflict Resolution Catalysts (CRC). Very often, peace building does not necessarily represent or occur at the end of the violence, but it makes peace enforcement necessary if the work of the littlest NGO is to bear fruit. It is

\footnotetext{
${ }^{19}$ ICG Bosnia Report \#16: “Elections in BiH”, Sarajevo, 22 September 1996, p.1.

${ }^{20}$ Ibid., p.59-62.

${ }^{21}$ Western, op. cit.

22 Martin A: Smith, "On Rocky Foundations: NATO, the UN and Peace Operations in the Post Cold War Era”, Bradford, Bradford University, Peace Research Report \#37, September 1996, p.58.
} 


\section{THE QUARTERLY JOURNAL}

certain that the international community's actions, however flawed they may be, deserve to be commended, not cancelled.

Rather, as David Last puts it, peace building is the term used for organizations seeking a new role. In Bosnia, it refers to the need to build trust among parties, an idea that "hinges on the belief that interests are not fundamentally inimical. ${ }^{23}$ The actions of the international community lead us to believe that the work to be done in Bosnia is not a matter of ethnic identity-a question that could raise controversy and arguments - but of bread-and-butter, negotiable issues. The USIP agrees with Crnobrnja, in that ethnic cleansing, for all its horrors, still proved an arduous task, and this fact confirms the possibility to live together. ${ }^{24}$

There are indications that existing enmity is not directly or inherently ethnic in character, but may be strategic, economic, or some combination of various elements. The issue of the Posavina corridor and the town of Brcko lends itself well to such an interpretation, as this area gives access to the Danube. Eastern Slavonia is also a case in point, as it is reputed to be oil-rich. ${ }^{25}$ Other similar claims can be made with regard to the Kosovo region, which would be the gateway for Caspian and Black Sea oil. But it is not because the UN or some other power believes in the fact that agreement is possible, given sufficient good will, that the Dayton Accords should be maintained. Dayton is but a stage $e^{26}$ in a peace process that promises to be long and protracted. Furthermore, negotiable issues do not preclude multi-ethnic coexistence.

When humanitarian work and armed factions are active simultaneously, this can and does convey the impression that nothing is settled and that nothing can be settled. Stopping parties from fighting is the business of the parties, true. But it is also the business of the international community, when it has a mandate to do so. Abdicators and revisionists are right to say that not all is well in Bosnia, but since they emphasize the persistence of residual tensions between communities, the impression one gets is that everyone prefers fighting to a peaceful solution.

This is not entirely accurate. One reason why there are obstacles to the implementation of Dayton is that the international community is only just now beginning to use a more robust approach to the problem. Before condemning the Dayton Accords, therefore, one would be wise to give international actors time to use all the tools at their disposal. The UN and other powers are trying a balancing act that requires substantial skill; to rid the Balkans (and other hot spots around the

\footnotetext{
${ }^{23}$ Major David M. Last, Theory and Practice of Conflict De-Escalation (Clementsport, Nova Scotia: Pearson Peacekeeping Centre Press, 1996), 27.

${ }^{24}$ Western, op. cit.

${ }^{25}$ Hans Binnendijk, ed., Strategic Assessment 1997 (Institute for National Strategic Studies, Fort Lesley J. McNair, 1997), p. 150-151.

${ }^{26}$ Jeremy King, "The Dayton Agreement: Perspectives on Dayton," Draft reading package for MND Southwest HQ Training Session, Kingston, Ontario, 8-20 August 2000, p. 2 (Quoting Xavier Bougarel).
} 
world) of war criminals without using methods whose precedents could be further detrimental to the existence of the nation-state as we know it. This accounts for a large part of the international community's incapacity. But, as I demonstrate later, such concerns are taking a back seat to the goal of bringing peace and justice to the Balkans.

David Last argues that the difficulties encountered at this stage of the peace process were foreseeable and normal. He concludes that the violence that led to the 1995 peace accords would inevitably lead to segregation. It is this sub-stage of peace building that is currently being overcome. Segregation will sooner or later lead to de-polarization, perhaps in another five years, perhaps with another $\$ 5$ billion. There are indications that Bosnia is de-polarizing already, with the election of its new government and the fact that the nationalist backlash it has triggered on the Croat and Serb side has not been echoed in the respective ethnic communities in Bosnia. ${ }^{27}$ In Croatian-held regions of Bosnia, members of the HDZ have allegedly started intimidating moderates and have called for police and army members to defect from Federation functions after SFOR troops tried to close a bank that allegedly funded aggressive nationalists in Bosnia. Interestingly, this initiative also figured in to the thinking of DPA believers at the USIP. ${ }^{28}$ This attempt has been shown to be failing; the army is not losing as many defectors as the HDZ would hope, and temporary deserters are now renewing their contracts with the moderate Federation government in ways that prevent their intimidation. ${ }^{29}$ The government in Croatia proper is not showing signs of support for separatists in the neighboring Federation, who find themselves political outcasts after the elections, whose rules were revised by the OSCE. ${ }^{30}$ The rules, criticized as "undemocratic" by EU officials, were specifically designed to exclude radical elements. It is thought that such elements are now running out of money and support, and this, more than the election rules, contributes to their radicalization. ${ }^{31}$ What's more (and which comes to the rescue of the notion that ethnic coexistence is possible), the radicals are highly localized. This confirms the belief that animosity is more created than inherent. Using international actors' power more efficiently (meaning more "aggressively") is a matter of common sense as much as it is a logical progression. Dealing with the few resistant elements the way that SFOR is doing prevents others from using the radical model to affect regional stability. The fact that this

\footnotetext{
27 "Bosnian Croats in Show of Support for Self-Rule", AFP, 12 April 2001, www.europeaninternet.com/bosnia/news.php3?id=367544. The article mentions only "several hundred peoples," indicating that the demonstrations were locally organized.

${ }^{28}$ Western, op. cit.

29 "One Quarter of Bosnian Croat Soldiers Claim Loyalty to Moderate Government", AFP, 25 April 2001, www.europeaninternet.com/bosnia/news.php3?id=388041 \&brief=text.

30 "OSCE Bosnia Election Rule Aided Radical Croats," Reuters, April 192001 , www.europeaninternet.com/bosnia/news.php3?id=382726.

31 "Bosnian Croat Nationalists Stir Violence - US Envoy," Reuters, April 232001 , www.europeaninternet.com/bosnia/news.php3?id=385543.
} 


\section{THE QUARTERLY JOURNAL}

model can affect stability is being verified as these lines are written, insofar as the Serb community, most probably under the influence of xenophobic leaders, is impeding the rebuilding of a mosque in Bosnia. ${ }^{32}$ There is no denying that they take after the recent tactics of the separatist HDZ. But in the Mostar Canton, where the HDZ is most prominent, the actions of the international community, which had drawn criticism just a few months ago, are succeeding. The HDZ is sending a delegation of parliamentarians back into the government to voice their grievances in a more legitimate fashion. This move was accompanied by calls for deserters to return to their barracks. ${ }^{33}$

Similarly, recent reports that there have been demonstrations organized by Serbs over the arbitration decision that would hand over a portion of Sarajevo to the Muslim-Croats operate almost in the same way, giving reason to High Representative Wolfgang Petritsch. ${ }^{34}$

Only after the de-polarization threshold has been crossed can the international community hope for reconciliation. ${ }^{35}$ At the present rate, we are looking at perhaps another fifteen to twenty years of involvement in the Balkans, and this is entirely normal. One indication that things are going according to theory (if not to plan) is the fact that the military presence is being reduced, despite the recent troubles outlined above. The constabulary presence continues to increase, with the help of a steady contingent of UN International Police Task Force (IPTF) training ever-greater numbers of indigenous police officers. When NATO took the field in 1995 , there were initially 60,000 troops, a number that was slashed by nearly half-and according to plan-to 32,000 the following year. Last year, numbers were reduced further, to 20000 , indicating tangible progress in the field. ${ }^{36} \mathrm{Sim}$ ilarly, the strength level of the IPTF, which reached 2011 in $1998,{ }^{37}$ has since decreased and is not to go over 1850 by order of the Secretary General. ${ }^{38}$

Calls for mass withdrawal would not only violate the theory, but also the common sense of the peace effort in Bosnia. The indications that can be mustered to determine whether the peace effort is going anywhere can be ascertained from the success of the UNMIBH and the military support it has received. But more to the point, the details of the mission and the information gathered from various reports identify the real source of friction in the implementation of Dayton and

\footnotetext{
32 "Serbs Scuttle Bosnia Mosque-building Ceremony," Reuters, May 6 2001, http://www.europeaninternet.com/centraleurope/news.php3?id=406180\&brief=text .

33 "Bosnian Croat Grouping Seeking Return to Government," AFP, 4 May 2001, www.europeaninternet.com/bosnia/news.php3?id $=402623$.

${ }^{34}$ Interview of UNHR Wolfgang Petritsch on "Simpson's World," BBC World, 4 May 2001, 070o GMT.

${ }^{35}$ Last, op. cit., p.122.

${ }^{36}$ www.nato.int/sfor.

${ }^{37} \mathrm{~S} / 1998 / 227$ and $\mathrm{S} / 1998 / 491$.

${ }^{38} \mathrm{~S} / 2000 / 1137$, para.35. At the same time, UNMIBH is expected to wrap up its mission in December 2002 .
} 
the achievement of workable ethnic relations. This is what I propose to examine in the next section.

\section{PART 3: Building trust and order}

The only way that multi-ethnic coexistence can be generated is through the building of trusting relations between communities. This is only possible, in turn, through the sort of good governance that is prescribed in the DPA provisions. In other words, the communities must learn to trust their institutions before they can trust each other. Inherent in this doctrine is the understanding that institutions in irresponsible hands do more harm than alleged centuries-old ethnic mistrust.

Good governance requires good people much more than good institutions. Jeremy King concluded in an overview of the security sector reform in Bosnia that, as long as political parties continue to be funded by criminal elements, change is unlikely. In another piece, he and former Canadian Defense Minister Jean-Jacques Blais argue that rebuilding war-torn societies is nearly impossible if the "political, social and economic environment in which reconstructed institutions must function is fundamentally hostile to the rule of law. ${ }^{39}$ What these authors are referring to are features of a functional society operating in conditions of positive peace. We will see that the residual resistance encountered in Bosnia revolves around the political sphere. One can tentatively assume that individuals, rather than communities, are at odds with the peace process. Let's see if this perception stands the test of reality.

Mihailo Crnobrnja is the first to admit that Dayton is but a halfway house to a resolution. He says that, "the political and military rulers made continuous efforts to accustom the people to believe there was no possibility of agreement because of the "other side." 40 The evidence shows that this Dayton-resistant leadership is currently embattled in Bosnia. Even the reports of the ICG and the reports of the UN Secretary General bear this out, and conclude that certain individuals and groups have a stake in keeping tensions high.

Is it possible to physically remove the impediments to the process? Initially, the UN attempted to deal with the symptoms of the conflict, in the belief that common sense would prevail and things would sort themselves out. They haven't. In order to control the mushrooming of illegal checkpoints in the early post-war days, the UN's IPTF introduced a policy whereby Respublika Srpska and Federation authorities would ask permission to hold checks of no longer than 30 minutes in the zone of separation. This led to a significant decrease between June and September of $1997 .{ }^{41}$ The introduction of a common "inter-ethnic" license plate further

\footnotetext{
39 Jean-Jacques Blais and Jeremy King, The Military, Human Security and the Rule of Law: Civil Military Cooperation in Post-Conflict Peace Processes, (Clementsport, Nova Scotia: Pearson Peacekeeping Centre, 2000). Tuition material from the PPC.

${ }^{40}$ Crnobrnja, op. cit.

${ }^{41} \mathrm{~S} / 1997 / 966$, para. 14.
} 


\section{THE QUARTERLY JOURNAL}

increased freedom of movement and decreased instances of illegal checkpoints. ${ }^{42}$ When the introduction of the plates was completed, however, the obstruction did not come from the field, but from Croat officials in cantons under their control. ${ }^{43}$ This may have had more to do with some Croats' desires of realizing the illegal (by Dayton standards) "Herceg-Bosna" para-State. ${ }^{44}$ The wrangling over the issue of insignias for the Federation police force participates in the same notion as an "independent Herceg-Bosna." ${ }^{45}$ By June 1999, the Secretary General reported that freedom of movement had ceased to be a pressing issue in Bosnia. ${ }^{46}$

However the change brought to peoples' lives by the common license plate operated in their minds, it is undeniable that it eased a lot of the tensions associated with moving about the country and has contributed to an impression of normality. Granted, it perhaps remains just an impression, but its effects cannot be denied. There may be room here for the idea that administrative multi-ethnicity can give way to civic multi-ethnicity. Even if small changes are imposed by the international community, these changes will nevertheless relieve the tensions between groups because resistant elements will not be able to proactively intimidate others, since ethnic boundaries will be blurred by egalitarian legal and administrative reform.

Another consequence was that the IPTF could start devoting more time to training local police in democratic law enforcement. Even provided that the laws exist, the notion that policemen can be trained to obey the rule of law is not evident, and the police will require continuous scrutiny from the international community. Suffice it to say that this is not an arbitrary goal; Bosnia needs a police force all sides can trust. The police force must operate in the interest of the law and not of the tribe. In any case, the IPTF could not continue the petty task of monitoring checkpoint violations. The increasing number of applicants for police duties made it urgent to set up training programs and facilities. The other issue was that the IPTF had a clear mandate to help create a genuine police force that would enforce laws autonomously. Its strength, for the whole of Bosnia, was to be $18,438 .{ }^{47}$ The fact that some IPTF officers were able to be transferred from Bosnian duty to Kosovo inevitably means that the police is already somewhat trustworthy. ${ }^{48}$

The emphasis on an independent and democratic police force follows the rationale that two things will allow a massive withdrawal of foreign troops from

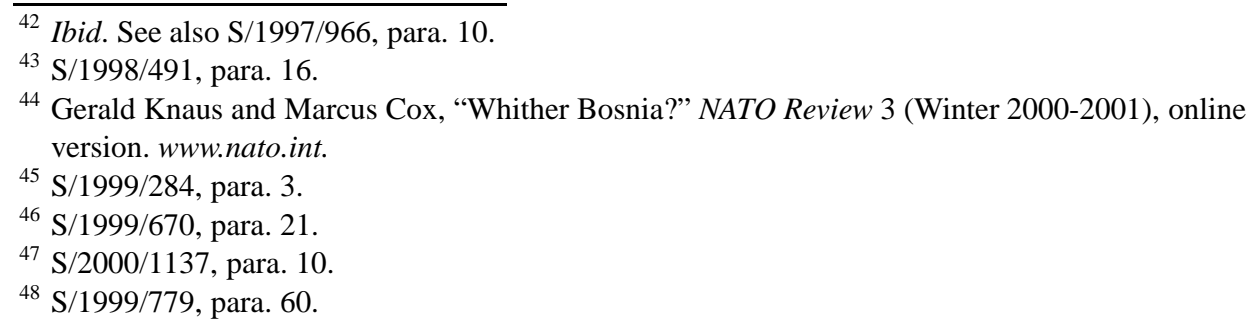


Bosnia. The first pertains to the medium term, and the second to the long term. In the medium term, it is hoped that the creation of a competent police force will generate new trust in authorities. For this trust to emerge, absolute and scrupulous observance of democratic policing principles and practices is essential. It will take less time to develop a police corps than to generate trust, which can only develop in the long term, but there is no other way. It is correctly believed that democratic policing should be sought as an end in itself, but the DPA's provisions initially promoted the initiative as a means to demonstrate that state power is representative and that it treats all communities the same. This is another example of "administrative" multi-ethnicity.

When sufficient policing capabilities have been mustered and when their level of competence is deemed satisfactory, then the international community will be able to contemplate a troop pullout. In early 2000 , the Secretary General was noting substantial progress from police restructuring, but still pointed at interference at the official level. ${ }^{49}$ What the experience of the IPTF reveals is that there are a number of people who are genuinely interested in participating in restoring democratic order in Bosnia. Furthermore, the calls of the Secretary General to use more robust methods ${ }^{50}$ to deny resistant officials the initiative to stall the peace process points not to the exasperation of the international community, but to the possibility of ridding Bosnia of troublemakers now that they are sufficiently isolated.

The coercive approach that has lately yielded some success has drawbacks, and was met with violence against IPTF forces in some cases. Such incidents are conspicuous for their occurrence so long after the signing of the DPA, but the same report states that the historic changes in Serbia open the door to real and meaningful security for the region, giving further credence to the notion that security depends on the good faith of the leaders and the effectiveness of state agencies, and not on their respective communities ${ }^{51}$.

This analysis echoes the belief that Crnobrnja has always held: the conflict revolves more around the predatory assertions of Croat and Serb leaders seeking their respective spheres of influence in Bosnia than around "ancient hatreds." "It took a long time and a lot of concentrated effort for nationalist zealots to exploit the ethnic differences of Bosnia," Crnobrnja notes. ${ }^{53}$

It is ironic that the solution advocated by abdicators would justify the existence of these spheres of influence, and would realize the goals of Milosevic and Tudjman better than the Dayton Accords ever could. The elements calling for ethnic separatism are less vocal than before, but fears and memories of the war lead people to vote along ethnic lines. "Safety in numbers" is the rationale behind ir-

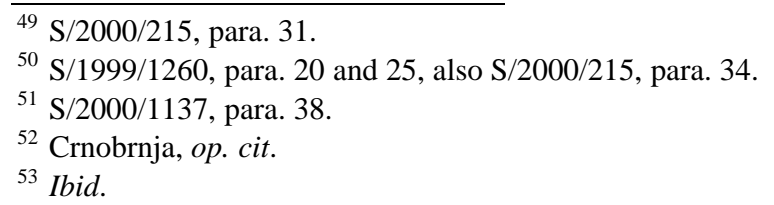




\section{THE QUARTERLY JOURNAL}

responsible claims of danger in electoral platforms. The Croat HDZ still made a strong showing because of such tactics in the November 2000 Bosnian elections, and the leader of the nationalist faction Ante Jelacic remains fiercely anti-Dayton and anti-Federation. ${ }^{54}$

However, the elections in Serbia proper have changed the complexion of the security situation. The mood in Bosnia may yet warm up to Dayton, making advocacy of scrapping the agreement premature. Milosevic's removal may help terminate Karadzic's influence in the Respublika Srpska. President Kostunica's position may well provide a platform for rapprochement of the communities, and recent hints at the possibility of a South African-style truth and reconciliation commis$\operatorname{sion}^{55}$ may yield the results that are hoped for in the region. But most importantly, it vindicates the thesis that the continuation of conflict revolves around a few individuals, and not the incompatibility of the communities or the shortcomings of the DPA.

Similarly, post-Tudjman Croatia has vowed not to challenge Bosnia's sovereignty. There is an increasing discrepancy between the activities of the nationalist party in Croatia and its pendant in Bosnia. Ante Jelacic may soon turn out to be an embarrassment to the political elite in Croatia proper that has resolutely decided to take on the task of meeting EU integration goals. This increased isolation makes the prospect of success in Bosnia more achievable, because it removes the imponderables stemming from the politics of neighboring states. It also has the prospect of radicalizing resistant elements, but, once again, the communities themselves cannot be blamed for this, and we should not expect a peace treaty to close the door to every political contingency the West doesn't like.

This points to the physical removal of those who obstruct the peace plan as key to the success sought in Bosnia. These officials hold on to their positions because of the material wealth and resources they gain from them. ${ }^{56}$ This would not merely remove impediments to the peace process; it would also promote economic conditions necessary for a lasting peace by returning these resources to the people. Despite its cynicism, even the ICG believes the Bosnians can live together. This is not a new concept; Crnobrnja describes how the multinational character of Bosnia is well ingrained, but he adds, "[t]his tolerance and blending of cultures most probably could have endured the country's conversion to democratic statehood, had it not been for the aggressive nationalism that spilled over....57

As a result, the ICG calls for a more consistent application of the international community's powers. ${ }^{58}$ The UN has anticipated these calls, and has shown itself

\footnotetext{
${ }^{54}$ Knaus and Cox, op. cit., and also ICG Report \#104, p. 10.

${ }^{55}$ Interview of President Kostunica in Davos by Amir Tahiri, London Al-Sharq al-Awsat, 15 Feb. 2001, p.7, via FBIS NTIS-WNC.

${ }^{56}$ ICG, op. cit., p. 8 and p. 19.

${ }^{57}$ Crnobrnja, op. cit. "The multi-ethnic character of Bosnia".

${ }^{58}$ ICG, op. cit., p.17.
} 
willing to take decisive action in service of the Dayton Accords. It was proactive in adopting measures that permitted the creation of a border police force. ${ }^{59}$ In a private conversation, Jeremy King has stressed that this police force is the only thing that works as intended in Bosnia. In late 1999, 22 officials who purposefully obstructed refugee returns were removed. ${ }^{60}$ The question of refugee returns is also one that can create difficulties, but the UNHCR has initiated the policy of "open cities," basically rewarding local officials with aid money if they help repatriation efforts. This is consistent with Kofi Annan's belief that carrots work better than sticks. ${ }^{61}$ While the task has proven more formidable than anyone has ever predicted, progress is being registered, and the lack of returnees can safely be attributed to the fact that those who have left will not be coming back, perhaps because they have chosen to remain where they are, either in the community of the majority elsewhere in Bosnia or the former Yugoslavia, or because they have successfully rebuilt their lives in other countries.

After having peaked at 253,000 in 1996, refugee returns dropped ${ }^{22}$ until 2000, which was a record year for returns because of increased stability. Further calls have been made in the hope of triggering further homecomings, especially in Respublika Srpska. ${ }^{63}$ The anomaly here is not the failure to see returns, but rather the weird provision of the Dayton Accords that allows people to vote in their former area of residence (why return?). This has the prospect of unduly shifting local electoral balances so that they do not represent the new reality on the ground. ${ }^{64}$ Neither the source nor the intent of this provision was ever made clear, but it is possible that it was designed to revert to the status quo ante or erase the past by nullifying the effects of ethnic cleansing. Such an attempt works at crosspurposes, as it only serves to remind the voters of the events that went on between 1991-1995. A full reversal is impossible, as Crnobrnja notes. ${ }^{65}$

Refugee returns are a means to undermine the power of nationalist elites resistant to change by bringing about local pluralism. It is not for purely ethnic reasons, but for political ones that returns are being prevented. It is as if the obstructionists know that democracy was just around the corner if returnees made their voices heard at the ballot boxes.

\footnotetext{
${ }^{59} \mathrm{~S} / 2000 / 215$, para. 33.

${ }^{60} \mathrm{~S} / 2000 / 1260$, para. 18.

${ }^{61}$ Woodhouse, op. cit., 14.

${ }^{62}$ Source: UNHCR Sarajevo.

63 "Bosnian Croat Nationalists Stir Violence - US Envoy," Reuters, April 232001 , www.europeaninternet.com/bosnia/news.php3?id $=385543$.

${ }^{64}$ General Framework Agreements, Annex 3, §4.1. While casting a ballot officially confirms the desire to return to the previous area of residence, it does not prevent voters from delaying their decision to return, and so these individuals may be exercising a bit of common sense before rebuilding their lives in an area whose stability is not assured yet.

${ }^{65}$ Crnobrnja, op. cit.
} 


\section{THE QUARTERLY JOURNAL}

Until 2000, returns had not materialized to the point where a legitimate overthrow of extremists was possible. This, in truth, is what the ICG and Friedman are condemning. Yet it is undeniable that "five years on, the nationalist power structures are fragmenting, undermined by the war-weariness of the population and the inexorable return to normality. use of the term "inexorable." But surely positive peace is taking root, no matter what the critics say. This is greatly due to the more assertive role that the Office of the High Representative has chosen. It is the improvement of the performance of national institutions that will help Bosnia achieve a sustainable peace, not a redrafting or the abandonment of the Dayton Accords. And, as we have argued, the performance of the institutions is forever tied with the integrity of the persons and institutions responsible for them in Bosnia, not to the fact that society is ethnically clean.

\section{Conclusion}

There remains a great deal to be done in Bosnia and, admittedly, difficulties still lie ahead, but they will be ironed out with the removal of obstructionists. Rather than a faulty peace deal, we are grappling with an international community unsure of what is to be done, as its actions carry consequences that could further undermine the existence of the nation-state. Attempting to decide everything for the Bosnians creates precedents for scores of developing countries recovering from war. Great power colonialism could be replaced by international organization colonialism, by security organization occupation.

Furthermore, what legitimacy will the Bosnian state have if everything is imposed from without? The Bosnians need to decide their future by themselves. In the end, the de-polarization that Last refers to may take a shape that is not intended by the international community, meaning that it may trigger the destruction of Bosnia, and the end of the desire to live together. But how different would that decision be from that taken by the Czechs and the Slovaks in the early 1990s? Of course, this outcome may be avoided if we stick faithfully to the Dayton Accords. Dayton is not a precise guidance tool, nor was it intended to be. Democracy can earn its name only when the people are empowered to affect the direction of their country. The decision to separate, were it to come, would be legitimate if made in a climate devoid of threats and intimidation, where the discourse is political and not coercive. A break up of Bosnia (or any other country, for that matter) is permissible only if the new states created by secession have a chance of being recognized as sovereign after the decision, and if the decision emerges out of informed, reasoned, measured, and responsible political debate, not from the paranoid ramblings of selfish and corrupt officials.

\footnotetext{
${ }^{66}$ Knaus and Cox, op. cit..
} 
Conflict theory analysis reveals that the peace process is not nearing its end, not because the premises on which it is based are faulty, but because it takes a long time to rebuild war-torn societies, period. It is the nature of the process and its goal-positive peace - that determine the time of completion, not the nature of the conflict. The DPA represents a legalized and binding truce with a road map to peace. The situation in which Bosnia finds itself now is a difficult crossroads. Some would say turn back, but there are more reasons to press on.

Evidence that the international community is adopting a more robust approach should be interpreted as an instance of success reinforcement, not imminent failure. As the implementation of the Accords becomes more systematic, and international actors' initiatives become more insistent, beneficial intransigence liable to propel the process into its final stage becomes possible. But as the UN Secretary General has put it in nearly all of his reports, for this to occur, donor fatigue must be combated, and the prospect of success emphasized.

The evolution of the role of the various security organizations, including that of NATO, which, according to King, is starting to resemble policy making, ${ }^{67}$ is not the result of frustration with the process, but indicates that the conflict may not be as intractable as first thought, and that practical, tangible solutions can be applied. As the results of the international actors compare more favorably in the eyes of the Bosnians to the failed promises of nationalists, it is quite likely that the communities will jettison obstacles to the peace process.

Friedman thinks that the debacle in Bosnia is so complete that McDonald's won't open its restaurants there. What the preceding essay has sought to demonstrate is that the international community's efforts are part of a concerted planthe DPA operating in harmony with countless private field NGOs and other actors. It has shown that these actors are confronted not by insurmountable ethnic differences, but by petty officials. The problem is certainly not the content or the spirit of the Dayton Accords, a mere stage in the peace process, but those individuals. For these reasons, despite the setbacks, we should stay the course with Dayton, and remind ourselves that positive peace does not come as fast and as cheaply as a burger and fries. Multi-ethnic coexistence is possible with the right ingredients. After all, what's a Big Mac without the secret sauce?

\footnotetext{
${ }^{67}$ Jeremy King, "Reviewing Security Sector Reform in Bosnia Herzegovina", unpublished draft paper from the Pearson Peacekeeping Centre, 2000, p. 4.
} 


\section{Bibliography}

Blais, Jean-Jacques, and Jeremy King. The Military, Human Security and the Rule of Law: Civil Military Cooperation in Post-Conflict Peace Processes. Clementsport, Nova Scotia: Pearson Peacekeeping Centre, 2000.

Friedman, Thomas L.. "Not Happening." New York Times (2001).

O’Hanlon, Michael. "Troops Partly Come Home." Foreign Affairs 80:2 (2001).

Smith, Martin. On Rocky Foundations: NATO, the UN and Peace Operations in the Post Cold War Era. Bradford, Bradford University, 1996.

Western, Jon. Bosnia's Next Five Years: Dayton and Beyond. Washington, D.C.: USIP, 2000.

Woodhouse, Tom. "International Conflict Resolution: Some Critiques and a Response." In Centre for Conflict Resolution citing International Alert, Goodhand \& Lewer, Goodhand \& Hume., 1999. 